\title{
26. A MASSIVE CARBONATE GRAVITY-FLOW DEPOSIT INTERCALATED IN THE LOWER MISSISSIPPI FAN ${ }^{1}$
}

\author{
Gregg R. Brooks, Larry J. Doyle, and Jennifer I. McNeillie, University of South Florida²
}

\begin{abstract}
The interval between 488.2 and $513.7 \mathrm{~m}$ below seafloor at Deep Sea Drilling Project (DSDP) Site 615 is interpreted as a single carbonate gravity-flow deposit. The deposit has characteristics of both a debris flow and a high-density turbidity current. Comparison of the sedimentary constituents in 15 samples from this site with samples from 26 core tops from the upper West Florida continental slope and eastern Mississippi Fan shows many similarities. Shallow-water indicators, such as mollusk and echinoid fragments, occur in both suites of samples. The West Florida continental margin, therefore, is a potential provenance area. The Yucatan slope is also a possible source, but data from it are limited.

The recognition of carbonate gravity-flow deposits intercalated within the Mississippi Fan refines our understanding of Pleistocene sedimentation within the Gulf basin. Deposition in the deep Gulf is dominated by the construction of the Mississippi Fan. However, this marine terrigenous depocenter is located between two large carbonate depocenters, the West Florida continental margin on the east and the Yucatan peninsula on the southwest. Periodically, the carbonate slope in these two regions fails, injecting carbonate gravity flows into the accreting terrigenous deep-sea fan.
\end{abstract}

\section{INTRODUCTION}

\section{Geologic Setting and Objectives}

The eastern deep Gulf of Mexico was dominated by construction of the Mississippi Fan during the Pleistocene. Paradoxically, the fan is bounded on the east and southwest by massive carbonate systems, the West Florida and Yucatan continental margins, respectively. The transition between clastic and carbonate sediments occurs abruptly at the foot of the slope (Doyle, 1983). Based on high-resolution seismic reflection data and piston cores, Doyle (1981, 1983), Holmes (1985), Doyle and Holmes (1985), and Walker (1984) have described a wide variety of carbonate gravity-flow deposits in the calcareous ooze of the West Florida upper slope and at the base of the West Florida Escarpment. Initiation of these gravity flows is attributed to slope failure due to instability caused by the relatively high rates of carbonate sedimentation, up to $60 \mathrm{~cm} / 1000$ yr. during certain portions of the Pleistocene (Doyle and Holmes, 1985). A similar scenario may apply to the Yucatan slope, although sedimentological information is limited to the mid-to-inner shelf (Logan et al., 1969).

Because of the ambiguity in terminology, we feel it necessary to define the gravity-flow processes that will be discussed throughout this chapter. The term "debris flow" is used for a gravity flow in which the larger grains are supported by a cohesive matrix (Lowe, 1979). Emplacement occurs by mass deposition resulting in a structureless, muddy deposit containing large clasts (Mutti and Ricci Lucci, 1975). "Turbidity current" is used when the sediment is supported by turbulence within the flow (Lowe, 1979). Emplacement can occur by mass deposi-

\footnotetext{
${ }^{1}$ Bouma, A. H., Coleman, J. M., Meyer, A. W., et al., Init. Repts. DSDP, 96: Washing. ton (U.S. Govt. Printing Office).

Address: (Brooks, Doyle, McNeillie) Department of Marine Science, University of South Florida, 140 Seventh Avenue South, St. Petersburg, FL 33701.
}

tion, in the case of a high-density turbidity current, or grain settling for lower density flows. High-density turbidity current deposits are commonly graded with low to high mud matrix content. Low-density flows typically contain the whole, or part of, the Bouma sequence with better segregation of grain sizes (Mutti and Ricci Lucci, 1975). Even though the two flows have different support mechanisms, they form a depositional continuum. During transport, the transition from mass flow to fluid (debris flow to turbidity current) occurs by dilution. Several different gravity-flow processes may occur in temporal sequence or even at the same time during transport and deposition (Nardin et al., 1979).

Site 615 is located in the southeast Gulf of Mexico on the lower Mississippi Fan about halfway between the West Florida and Yucatan continental margins (Fig. 1). At a sub-bottom depth between 485.2 and $514.95 \mathrm{~m}$ below seafloor (BSF), a 29-m-thick unit composed of sandy carbonate biogenic material was described by the shipboard scientists and was interpreted to represent a gravity-flow deposit (see Site 615 chapter, this volume). Biostratigraphic studies indicate that the unit was deposited during the Wisconsin Interstadial, somewhere between 85,000 and 127,000 yr. ago during Ericson Zone X (Ericson and Wollin, 1968; B. Kohl, personal communication, 1985). Our initial proposal to DSDP to study Leg 96 samples predicted the presence of such layers. The objective of this investigation was to study this carbonate-rich sequence to assess its initial interpretation as a carbonate gravity-flow deposit, and to determine, if possible, its provenance.

\section{METHODS}

A total of 15 samples from Site 615 from the interval between 485 and $515 \mathrm{~m}$ BSF was acquired for analysis. All samples were analyzed for texture by standard sieve and pipette methods (Folk, 1965). Sediment constituent composition was determined on the sand-sized fraction by visual estimation under the light microscope. In addition, constituent composition was determined in the same manner on samples 


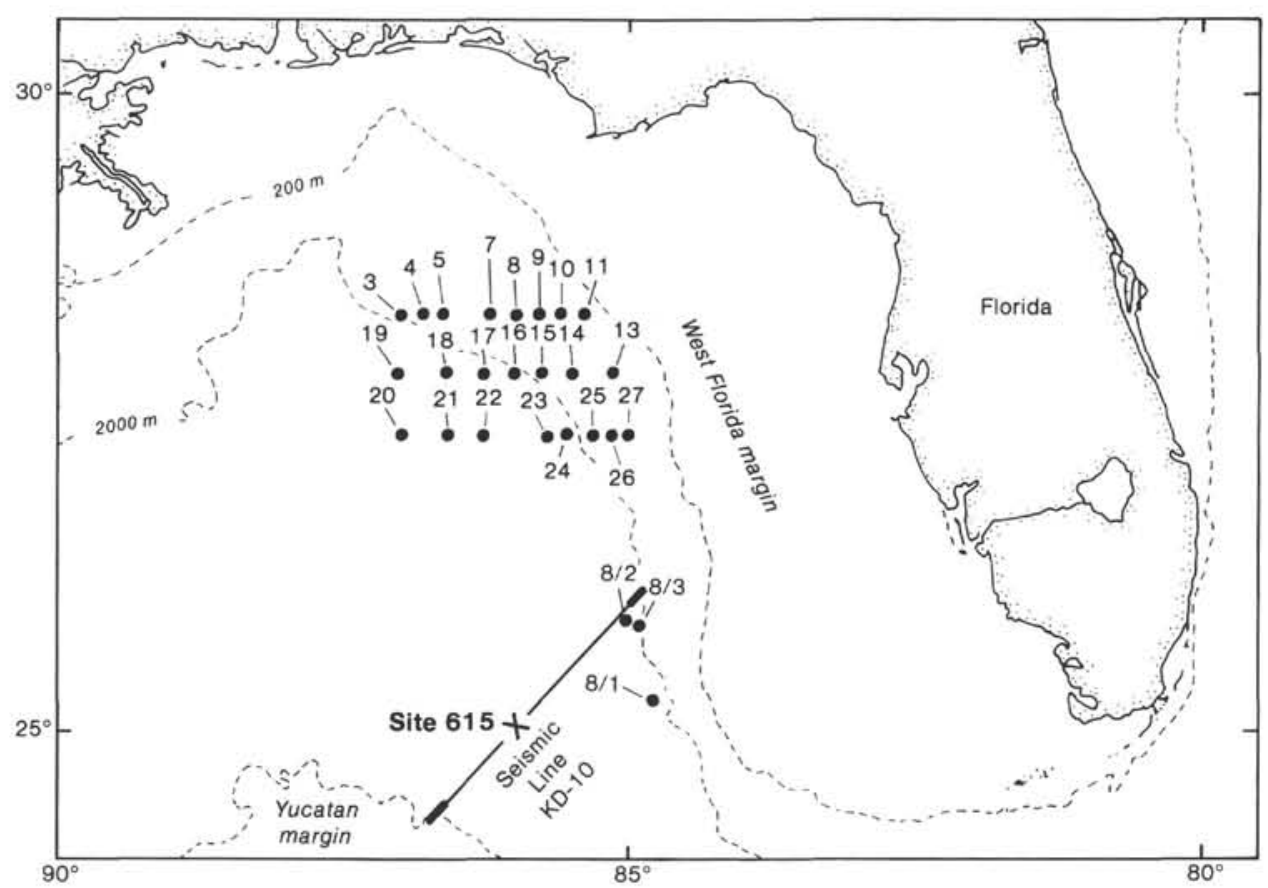

Figure 1. Map of eastern Gulf of Mexico showing location of DSDP Site 615 and its proximity to the West Florida and Yucatan continental margins. Also shown is location of seismic line KD-10 (segments shown in Fig. 6 are indicated by the thicker parts of the line) and location of piston cores that were used for comparison with samples from Site 615. Cores collected by University of South Florida/ USGS Gyre G80-6 cruise in 1980 and G81-8 cruise in 1981.

from core tops from a suite of 26 piston cores from the West Florida upper continental slope and the easternmost limb of the Mississippi Fan (Fig. 1). Constituent data from the eastern Gulf cores were then compared with the samples from Site 615. Calcium carbonate content of Sample 615-51,CC was determined using the acid leaching method (Milliman, 1974). All other values were determined on board ship by the carbonate bomb method (see Explanatory Notes, this volume). The fine $(<63 \mu \mathrm{m})$ fraction of selected samples were examined by scanning electron microscopy (SEM).

\section{RESULTS}

Figure 2 shows the gross texture, percentage carbonate, and our interpretation of the sediment types downhole at Site 615 . The interval between 488.2 and $513.7 \mathrm{~m}$ BSF has a relatively high percentage of carbonate. Between 505.3 and $511.3 \mathrm{~m} \mathrm{BSF}$, the content of sand-sized material increases to as much as $35 \%$. Table 1 shows the constituents in the sand fraction. The interval between 502.4 and $513.7 \mathrm{~m}$ BSF contains shelf indicators, such as fragments of coralline algae, Halimeda flakes, mollusk fragments, echinoid spines, and sponge spicules. Some examples are shown in Figure 3. Near the bottom of the sequence, in Samples 615-51-8, 15-17 cm and 615-51, CC, fragments of coralline algae and mollusks are common with other shallow-water indicators in rare or trace amounts. Upcore, mollusk fragments remain common in all samples but Sample 615-51-5, 15-17 cm. Coralline algae are found in rare or trace amounts in only two samples above $512.8 \mathrm{~m}$ BSF. Above $505.3 \mathrm{~m}$ BSF (Sample 615-51-2, 15-17 cm), shallow-water indicators within the carbonate sequence are essentially absent. Content of sand-sized material continues to decrease upcore. The highest carbonate percentages $(81 \%)$ are also near the top of the carbonate sequence. Quartz sand-sized particles are common to abundant in the sandy portion of the sequence, but rare to absent in the fine portion above 505.3 m BSF (Sample 615-51-2, 15-17 cm).

Table 2 shows the results of constituent analysis of samples from the tops of the eastern Gulf piston cores (Fig. 1). Comparison of sediment constituents from Tables 1 and 2 shows many similarities between the carbonate deposit at Site 615 and the sediments of the eastern Gulf margin.

\section{DISCUSSION}

\section{Single Gravity-Flow or Multiple Events}

Based on texture and composition we have divided the entire 29-m interval between 485.2 and $514.95 \mathrm{~m}$ BSF into three basic sedimentologic categories (Fig. 2). The three categories-pelagic, gravity flow, and terrigenousconsist of different types of sediments that reflect different modes of deposition. The bottom sample (615-52-1, $72-74 \mathrm{~cm}$ ) at $514.4 \mathrm{~m}$ BSF lies beneath the gravity-flow deposit and is interpreted to represent pelagic sedimentation. It consists of over $75 \%$ silt- and clay-sized material. Of this, more than $50 \%$ is clay-sized, which is dominated by calcareous nannofossils with only trace amounts of terrigenous clastics (Fig. 4; Site 615 chapter, this volume). The sand-sized fraction, which accounts for less than $25 \%$, is dominated by planktonic foraminifers (Table 1). The interval between 499.4 and $513.7 \mathrm{~m} \mathrm{BSF}$ is interpreted to be a single carbonate gravity-flow deposit. It consists of between 25 and $35 \%$ sand-sized material (Fig. 2) with considerable amounts of shelf-derived car- 


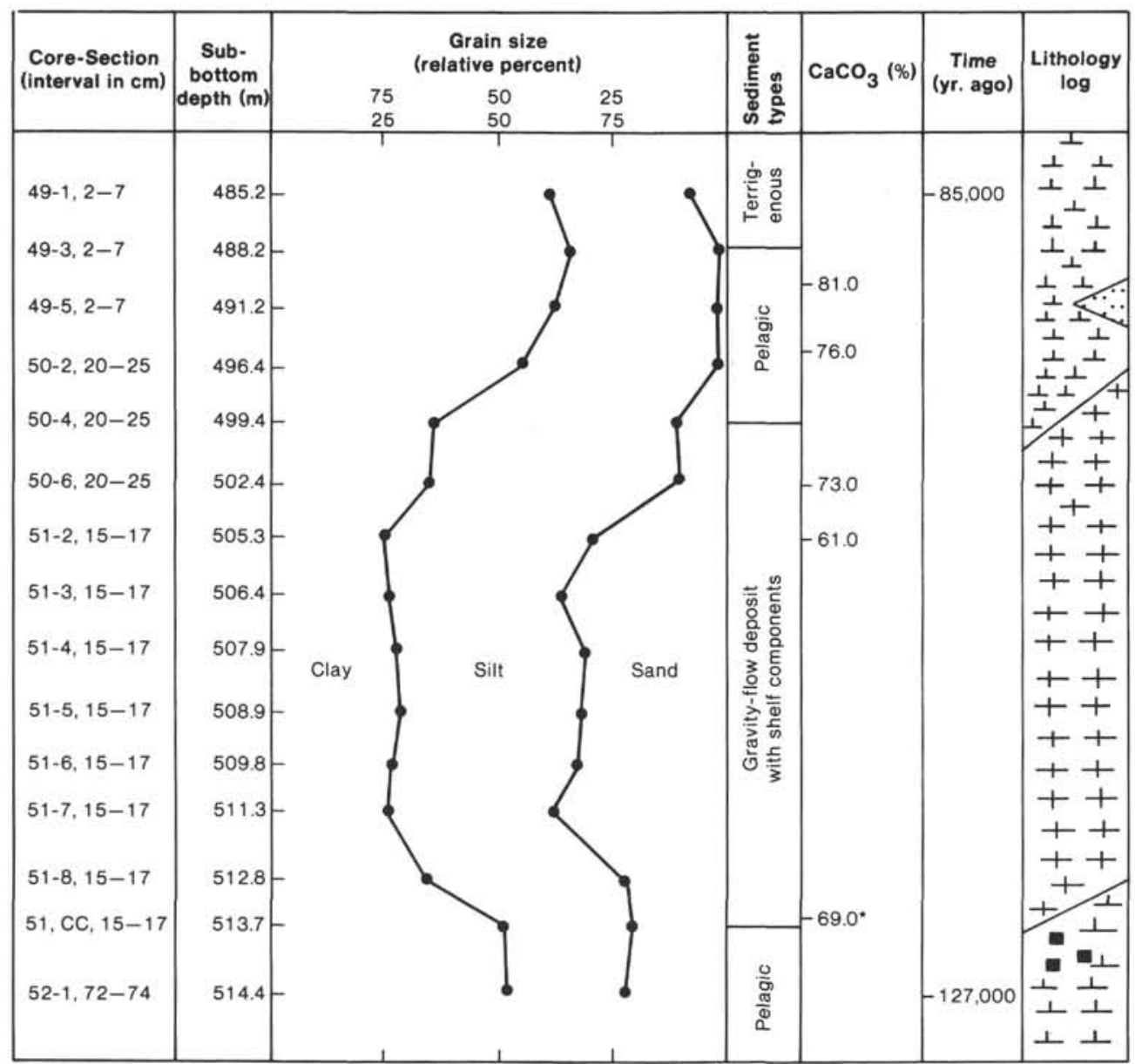

Figure 2. Distribution of texture, $\mathrm{CaCO}_{3}(\%)$, and sediment types within the carbonate unit recovered at Site 615. (Asterisk denotes $\mathrm{CaCO}_{3}(\%)$ in Sample 615-51, CC determined by acid leaching; all others determined by carbonate bomb on board ship. See Explanatory Notes for interpretation of symbols in lithology log. Filled boxes at bottom represent rock fragments.)

Table 1. Carbonate constituents and quartz in the sand-sized fraction, Site 615.

\begin{tabular}{|c|c|c|c|c|c|c|c|c|c|c|c|c|c|c|c|}
\hline \multirow[b]{2}{*}{ Constituent } & \multicolumn{15}{|c|}{ Core-Section (interval in $\mathrm{cm}$ ) } \\
\hline & $\begin{array}{c}49-1 \\
2-7\end{array}$ & $\begin{array}{c}49-3 \\
2-7\end{array}$ & $\begin{array}{c}49-5 \\
2-7\end{array}$ & $\begin{array}{c}50-2, \\
20-25\end{array}$ & $\begin{array}{c}50-4 \\
20-25\end{array}$ & $\begin{array}{l}50-6 \text {, } \\
20-25\end{array}$ & $\begin{array}{c}51-2 \\
15-25\end{array}$ & $\begin{array}{l}51-3, \\
15-17\end{array}$ & $\begin{array}{l}51-4, \\
15-17\end{array}$ & $\begin{array}{c}51-5 \\
15-17\end{array}$ & $\begin{array}{l}51-6, \\
15-17\end{array}$ & $\begin{array}{l}51-7 \\
15-17\end{array}$ & $\begin{array}{c}51-8 \\
15-17\end{array}$ & $\begin{array}{l}51, \mathrm{CC}, \\
15-17\end{array}$ & $\begin{array}{l}52-1, \\
72-74\end{array}$ \\
\hline Benthic foraminifers & $\mathbf{R}$ & - & - & - & - & D & $\mathrm{C}$ & $\mathrm{C}$ & C & - & C & C & $\mathrm{C}$ & C & - \\
\hline Planktonic foraminifers & $\mathrm{R}$ & D & D & A & D & - & A & A & A & D & A & A & A & A & D \\
\hline Echinoids & - & - & - & - & - & - & - & - & tr & - & tr & tr & - & - & - \\
\hline Mollusk fragments & - & - & - & $\mathbf{R}$ & - & - & C & C & $\mathrm{C}$ & - & C & C & $\mathrm{C}$ & C & - \\
\hline Pteropods & - & - & - & - & - & $\mathbf{R}$ & tr & $\mathrm{C}$ & - & - & $\mathbf{R}$ & $\mathbf{R}$ & $\mathbf{R}$ & $\mathbf{R}$ & - \\
\hline Ostracods & - & - & - & - & - & - & - & - & - & - & - & tr & - & - & - \\
\hline Halimeda & - & - & - & - & - & - & - & - & - & - & - & - & - & $\mathbf{R}$ & - \\
\hline Coralline algae & - & - & - & - & - & - & - & - & tr & - & $\mathbf{R}$ & - & $\mathrm{C}$ & C & - \\
\hline Sponge spicules & - & - & - & C & - & $\mathbf{R}$ & - & $\mathbf{R}$ & - & - & $\hat{R}$ & $\mathbf{R}$ & - & C & - \\
\hline Quartz grains & D & - & - & $\mathbf{R}$ & $\operatorname{tr}$ & R & A & $\ddot{A}$ & C & - & C & C & A & A & - \\
\hline
\end{tabular}

Note: $\mathrm{D}=$ dominant $(50 \%) ; \mathrm{A}=$ abundant $(25-50 \%) ; \mathrm{C}=$ common $(10-25 \%) ; \mathrm{R}=$ rare $(1-10 \%) ; \mathrm{tr}=$ trace $(1 \%) ;-=$ no occurrence.

bonate clasts (Table 1). The basal portion (512.8-513.7 $\mathrm{m}$ BSF) is interpreted to represent a debris-flow deposit because coarse sand- and granule-sized angular lithoclasts were found in each of the two samples representing this interval. Additionally, both samples contain more than $75 \%$ silt- and clay-sized material (Fig. 2), enough to supply the required matrix strength for support of the lithoclasts. Upcore, the absence of lithoclasts, the dra- matic increase in amount of sand-sized material to over $35 \%$ (between 506.4 and $511.3 \mathrm{~m} \mathrm{BSF}$ ), and subsequent grading above this (between 496.4 and $506.4 \mathrm{~m}$ BSF) supports our contention of deposition from a high-density turbidity current.

The flow probably originated as a debris flow and evolved into a turbidity current. Middleton and Hampton (1973) and Lowe (1979) both pointed out that such 


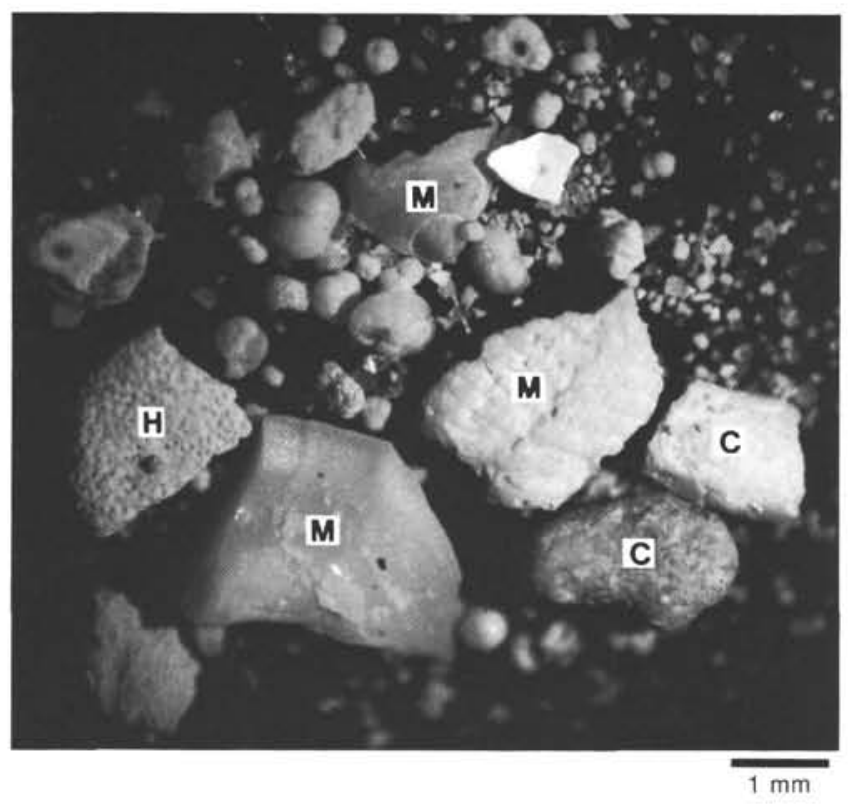

Figure 3. Photograph of typical sediment assemblage from Sample $615-51, \mathrm{CC}$. Note presence of shallow water components. $\mathrm{M}=$ mollusk fragments, $\mathrm{H}=$ Halimeda, $\mathrm{C}=$ coralline algae.

an evolution is common in gravity-flow processes. Crevello and Schlager (1980) discovered a turbidite with a basal debris flow unit in Exuma Sound, Bahamas. Coincidentally, based upon nannofossil and planktonic foraminiferal data, the entire sequence was deposited between 80,000 and $120,000 \mathrm{yr}$, ago, the same time interval as the deposit at Site 615. The basal unit of the Exuma Sound deposit reaches a thickness of 2 to $3 \mathrm{~m}$, similar to our interpretation for Site 615 .

Between 488.2 and $499.4 \mathrm{~m}$ BSF is another pelagic interval consisting primarily of nannofossils (see Site 615 chapter, this volume). We interpret the top sample in our section $(615-49-1,2-7 \mathrm{~cm})$ at $485.2 \mathrm{~m}$ BSF as hemipelagic because of the increase in detrital quartz sand to about $15 \%$ (Table 1). The silt and clay fraction is still dominantly a nannofossil ooze (Fig. 5) (see Site 615 chapter, this volume).

We favor the interpretation of the entire interval between $488.2 \mathrm{~m}$ BSF (Sample 615-49-3, 2-7 cm) and 514.7 m BSF (Sample 615-51,CC) as a single unit because of the progressive loss of continental margin diagnostics uphole, the concentration of finest grained carbonate with little sand-sized material near the top, and the lack

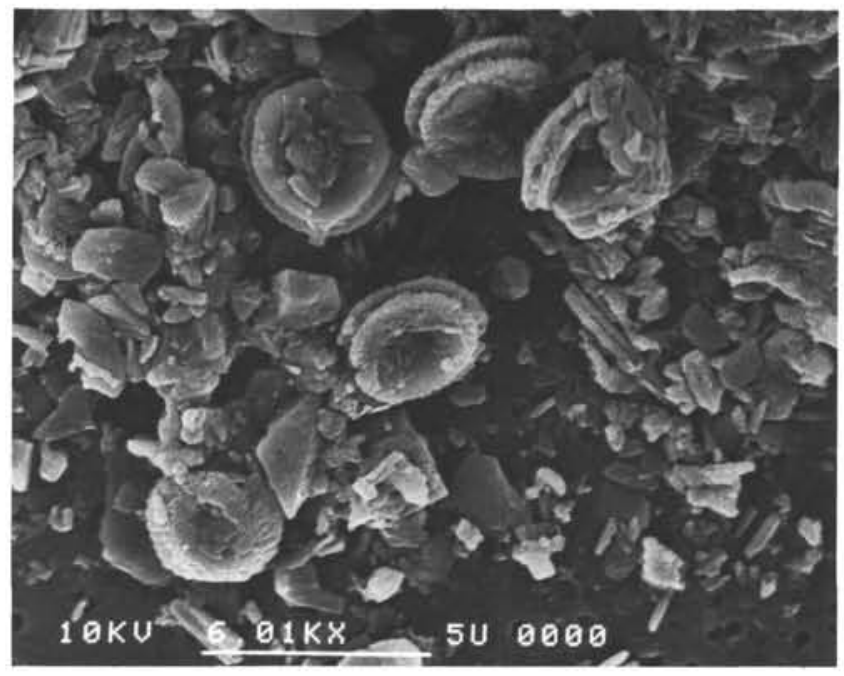

Figure 4. Scanning electron micrograph of Sample 615-52-1, 72-74 cm showing abundance of calcareous nannofossils.

of sharp textural breaks (see Site 615 chapter, this volume) or evidence of the presence of dominant Mississippi River system-derived clastics within the carbonate sequence. The sand-sized particles that are in the "pelagic" segment of the carbonate unit $78.5 \%$ carbonate average of two measurements) are dominantly planktonic foraminifers with no quartz. We interpret this fine, carbonate-rich interval as the $T_{e}$ division of the Bouma sequence.

Alternative interpretations are possible, of course, and we lack the data to reach an unambiguous conclusion. Another possible interpretation is that the carbonate sequence is composed of a number of smaller density-flow deposits. There are a number of characteristics in some of the samples that could be used to support this contention. For instance, coralline algae is a common constituent of the bottom two samples of the sequence, Samples 615-51-8, 15-17 cm and 615-51,CC. Sample 615$51-5,15-17 \mathrm{~cm}$ at $508.9 \mathrm{~m}$ BSF is dominated by planktonic foraminifers with no margin diagnostics. Also, the fine carbonates on top of the sequence could represent normal pelagic sedimentation.

However, we contend that if the unit represents multiple events, more variation of texture and constituents should be expected downhole, reflecting density-flow and nondensity-flow intervals. The lithology log (Fig. 2) shows no major variations throughout the carbonate unit. Simi-

Table 2. Sediment constituents and quartz in the sand-sized fraction, West Florida slope and Eastern Mississippi Cone piston cores. ${ }^{a}$

\begin{tabular}{|c|c|c|c|c|c|c|c|c|c|c|c|c|c|c|c|c|c|c|c|c|c|c|c|c|c|c|}
\hline \multirow[b]{2}{*}{ Constituent } & \multirow[b]{2}{*}{$6 / 3$} & \multirow[b]{2}{*}{$6 / 4$} & \multirow[b]{2}{*}{$6 / 5$} & \multirow[b]{2}{*}{$6 / 7$} & \multirow[b]{2}{*}{$6 / 8$} & \multirow[b]{2}{*}{$6 / 9$} & \multirow[b]{2}{*}{$6 / 10$} & \multirow[b]{2}{*}{$6 / 11$} & \multirow[b]{2}{*}{$6 / 13$} & \multirow[b]{2}{*}{$6 / 14$} & \multirow[b]{2}{*}{$6 / 15$} & \multicolumn{3}{|c|}{ G80 } & \multirow[b]{2}{*}{$6 / 19$} & \multirow[b]{2}{*}{$6 / 20$} & \multirow[b]{2}{*}{$6 / 21$} & \multirow[b]{2}{*}{$6 / 22$} & \multirow[b]{2}{*}{$6 / 23$} & \multirow[b]{2}{*}{$6 / 24$} & \multirow[b]{2}{*}{$6 / 25$} & \multirow[b]{2}{*}{$6 / 26$} & \multirow[b]{2}{*}{$6 / 27$} & \multicolumn{3}{|c|}{ G81 } \\
\hline & & & & & & & & & & & & $6 / 16$ & $6 / 17$ & $6 / 18$ & & & & & & & & & & $8 / 1$ & $8 / 2$ & $8 / 3$ \\
\hline Benthic foraminifers & c & $\mathbf{R}$ & c & $\mathbf{R}$ & $\mathbf{R}$ & c & c & A & $\mathrm{R}$ & c & $\mathbf{R}$ & is & tr & tr & tr & - & c & - & $\mathrm{R}$ & C & C & $\mathbf{R}$ & $\mathbf{R}$ & C & $\mathbf{R}$ & $\mathbf{R}$ \\
\hline Planktonic foraminifers & A & D & A & D & A & A & A & A & D & A & D & D & D & A & D & R & A & A & D & D & D & D & $\hat{D}$ & D & D & D \\
\hline Echinoids & c & $\mathbf{R}$ & $\mathbf{R}$ & tr & $\mathbf{R}$ & c & $\mathrm{c}$ & c & $\mathbf{R}$ & tr & c & c & $\mathbf{R}$ & $\mathrm{R}$ & $\mathbf{R}$ & tr & c & - & $R$ & c & C & $\mathbf{R}$ & c & $\mathbf{R}$ & $\mathbf{R}$ & R \\
\hline Mollusk fragments & c & C & c & C & C & c & A & A & c & A & c & c & $\mathbf{R}$ & C & $\mathbf{R}$ & $\mathbf{R}$ & A & c & $\mathbf{R}$ & c & c & $\mathbf{R}$ & c & $\mathrm{R}$ & R & R \\
\hline Pteropods & $\mathbf{R}$ & $\mathbf{R}$ & $\mathbf{R}$ & $\mathbf{R}$ & $\mathbf{R}$ & $\mathbf{R}$ & $\mathbf{R}$ & R & $\mathbf{R}$ & tr & c & $\mathbf{R}$ & $\mathbf{R}$ & tr & R & tr & tr & - & R & c & c & $\mathbf{R}$ & c & tr & tr & $\mathrm{tr}$ \\
\hline Ostracods & tr & - & - & - & tr & - & - & R & - & tr & R & tr & $\mathbf{R}$ & - & tr & - & $\mathrm{R}$ & - & tr & c & c & - & - & - & - & - \\
\hline Halimeda & - & - & - & - & - & - & - & - & - & - & - & - & - & - & - & - & - & - & - & - & - & - & - & - & - & - \\
\hline Coralline algae & - & - & - & - & - & - & - & - & - & - & - & - & - & - & - & - & - & - & - & - & - & - & - & - & - & - \\
\hline Sponge spicules & - & - & - & - & - & - & - & tr & - & $\mathrm{tr}$ & - & - & - & - & - & - & - & - & - & tr & tr & - & - & - & - & - \\
\hline Quartz grains & tr & - & - & - & - & tr & - & - & - & - & - & - & tr & c & - & R & - & A & - & - & - & tr & - & R & R & - \\
\hline
\end{tabular}

Note: $\mathrm{D}=$ dominant $(50 \%) ; \mathrm{A}=$ abundant $(25-50 \%) ; \mathrm{C}=\operatorname{common}(10-25 \%) ; \mathrm{R}=$ rare $(1-10 \%) ; \mathrm{tr}=$ trace $(1 \%) ;-=$ no occurrence.

Locations of cores shown in Figure 1 . 


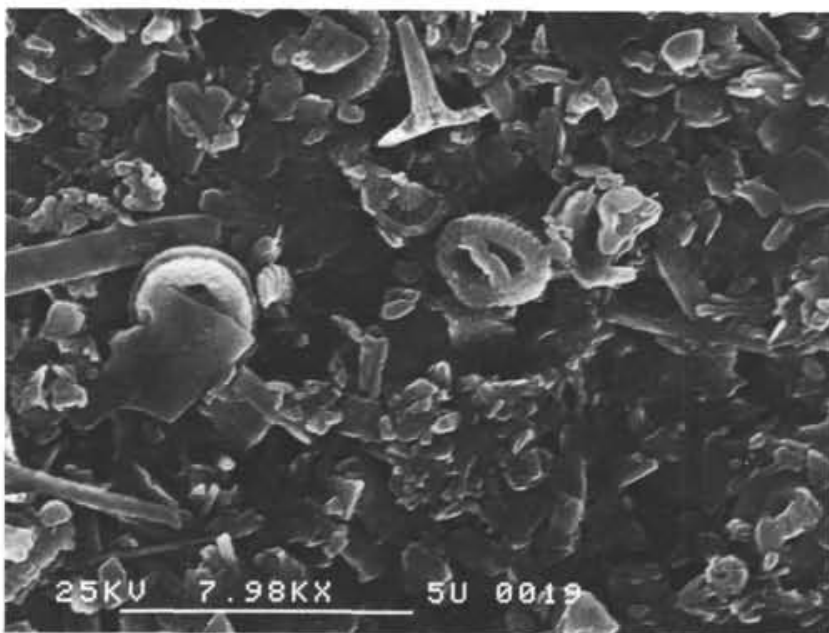

Figure 5. Scanning electron micrograph of Sample 615-49-1, 2-7 cm showing abundance of calcareous nannofossils.

larly, with the exception of Sample 615-51-5, 15-17 cm, at $508.9 \mathrm{~m}$ BSF, mollusk fragments remain a common constituent of the sand-sized fraction throughout the section. Quartz remains relatively constant throughout the section as well. No major shifts in grain size or horizons of lutite dominated by Mississippi River system clastics are present as would be expected if multiple events had occurred.

The most straightforward interpretation, therefore, remains a single event. This interpretation is further supported by a seismic profile, the location of which is shown in Figure 1. This profile shows a unit correlative to the carbonate sequence extending across the entire width of the fan and onlapping the base of both the Yucatan slope and the West Florida Escarpment (Fig. 6). No irregularities in the reflecting horizon that would suggest multiple events are evident.

\section{Provenance}

There are two potential source areas for the carbonates, the West Florida margin and the Yucatan margin. The Yucatan shelf contains a "chlorazoan" sediment assemblage, typical of tropical conditions (Ward, 1976; Logan et al., 1969), dominated by coral fragments and coralline algae. Very little data are available from the Yucatan slope, however, so its potential as a source for the carbonate sequence at Site 615 is difficult to assess.

Comparison of the data in Table 2 with those of Table 1 shows that the West Florida margin does have good potential as a source area. West Florida slope sediments are primarily a planktonic foraminiferal-nannofossil ooze containing a considerable quantity of shallow-water carbonate material from the adjacent shelf (Doyle and Holmes, 1985). Mollusk fragments are common to abundant in most samples, reflecting the dominant constituents of the shelf surface veneer (Doyle and Sparks, 1980). Coralline algae and Halimeda are not common in samples from the tops of the eastern Gulf cores, but should be more common in sediments to the south where more of these constituents can be expected on the shelf. Echinoids are common on the upper slope but become thinned out at the base of the escarpment and out onto the eastern limb of the fan. The West Florida slope, therefore, could be provenance for both the shallow-water-derived carbonate material as well as much of the pelagic material discovered between 499.4 and $513.7 \mathrm{~m} \mathrm{BSF}$ at Site 615 .

One aspect in which the samples are clearly different is in the quartz content of the sands. The West Florida upper continental slope surface sediments contain very little quartz. There are at least two possible explanations for the presence of the quartz at Site 615. First, as the flow moved across the Gulf basin floor at relatively high speed, it is reasonable to assume that some terrigenous clastics from the underlying Mississippi Fan deposits could

NE

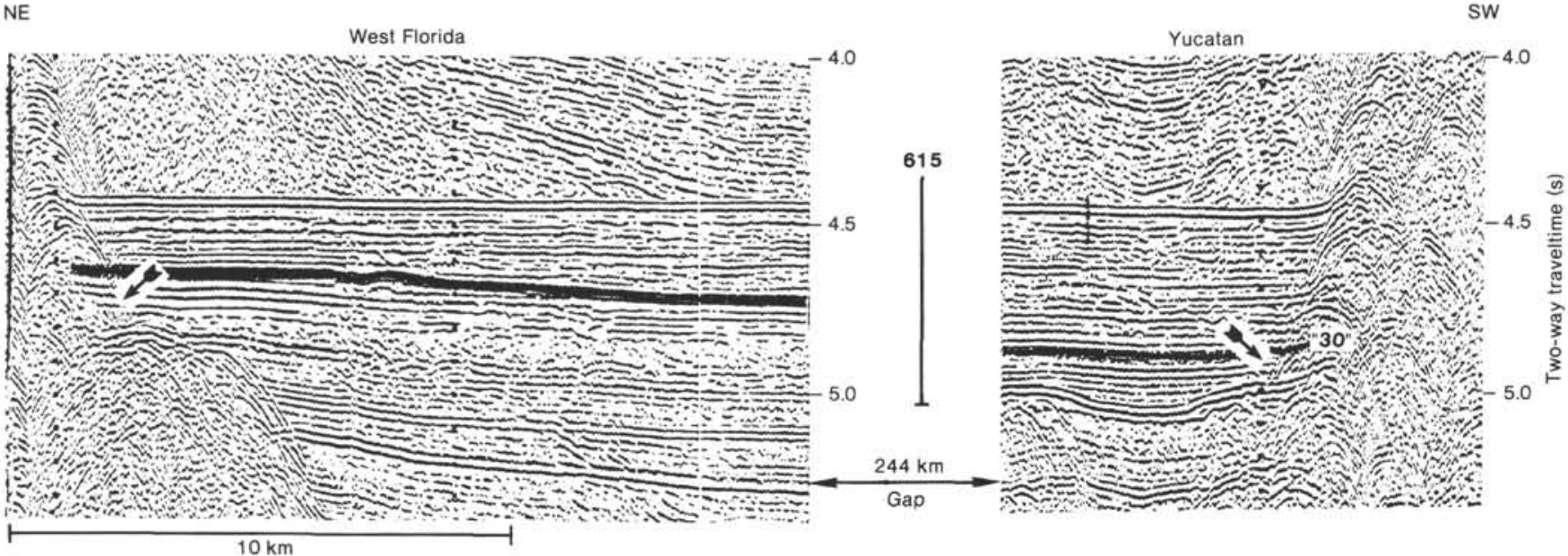

Figure 6. Parts of seismic (160 KJ sparker) Profile KD-10 (Kane 1969 cruise) showing massive turbidite unit (shown by arrows) beneath seismic Horizon "30" onlapping the West Florida and Yucatan margins (see Stelting et al., this volume). Site 615 is located in the gap (approximately midway between the two segments). Location of line segments is shown in Figure 1. (Data courtesy of Charles E. Stelting.) 
have become incorporated with the carbonate material in the gravity flow. Alternatively, Doyle (1981) pointed out that during lowered sea level, the rivers of Florida become rejuvenated, erode the Tertiary quartz sand terraces of peninsular Florida, and carry the quartz sand onto the dominantly carbonate platform. Therefore, the Pleistocene section can reasonably be expected to contain intervals of higher quartz content than that represented by the Holocene material recovered from the tops of the West Florida upper slope cores.

\section{SUMMARY AND CONCLUSIONS}

Results from textural and constituent analyses of 15 samples from Site 615 are consistent with the shipboard interpretation of a gravity-flow deposit between 488 and $514 \mathrm{~m}$ BSF. We interpret this sequence, which reaches $25.5 \mathrm{~m}$ in thickness at this point, to be a massive gravity-flow deposit featuring debris-flow and high-density turbidity current characteristics. Comparison of the sediment constituents with those from core tops from a suite of 26 piston cores from the eastern flank of the Mississippi Fan and the West Florida upper slope suggests that the latter is a potential source for the carbonate gravityflow deposit. The Yucatan Peninsula is also a possible source, but evaluation is difficult because of the lack of data on the slope facies of that region.

The presence of carbonate gravity-flow deposits intercalated in the Mississippi Fan leads to the following scenario for Pleistocene deposition in the deep Gulf ba$\sin$. The deep eastern Gulf is dominated by clastic sedimentation and the buildup on the Mississippi Fan. This major clastic depocenter is bounded on the east by the carbonate depocenter of the West Florida margin and on the southwest by the carbonate Yucatan Peninsula. Carbonate buildup on the continental slopes of the bounding margins is sufficient to initiate major gravity-flow events that periodically inject shallow-water carbonate material into the otherwise clastic-dominated Mississippi Fan.

\section{ACKNOWLEDGMENTS}

An earlier draft of this paper was reviewed by David J. W. Piper and Charles Holmes.

\section{REFERENCES}

Crevello, P. D., and Schlager, W., 1980. Carbonate debris sheets and turbidites, Exuma Sound, Bahamas. J. Sediment. Petrol., 50:11211148.
Doyle, L. J., 1981. Depositional systems of the continental margin of the eastern Gulf of Mexico west of peninsular Florida: a possible modern analog to some depositional models for the Permian Delaware Basin. Gulf Coast Assoc. Geol. Soc., 31:279-282.

1983. Shallow structure and stratigraphy of the carbonate West Florida continental slope and their implications to sedimentation and geohazards. USGS Open File Rept. 830425, p. 19.

Doyle, L. J., and Holmes, C. W., 1985. Shallow structure, stratigraphy and carbonate sedimentary processes of the West Florida upper continental slope. Am. Assoc. Pet. Geol. Bull., 69:1133-1144.

Doyle, L. J., and Sparks, T. N., 1980. Sediments of the Mississippi, Alabama, and Florida (MAFLA) continental shelf. J. Sediment. Petrol., 50:905-916.

Ericson, D. B., and Wollin, G., 1968. Pleistocene climates and chronology in deep-sea sediments. Science, 162:1127-1234.

Folk, R. L., 1965. Petrology of Sedimentary Rocks: Austin (Hemphills).

Holmes, C. W., 1985. Accretion on the south Florida platform, late Quaternary development. Am. Assoc. Pet. Geol. Bull., 69:149-160.

Logan, B. W., Harding, J. L., Ahr, W. M., Williams, J. D., and Snead, R. G., 1969. Late Quaternary carbonate sediments of Yucatan shelf, Mexico. In Logan, B. W., Harding, J. L., Ahr, W. M., Williams, J. D., and Snead, R. G. (Eds.), Carbonate Sediments and Reefs, Yucatan Shelf: Mexico: Tulsa (Am. Assoc. Pet. Geol. Mem.), 11: 129-198.

Lowe, D. R., 1979. Sediment gravity flows: their classification and some problems of application to natural flows and deposits. In Doyle, L. J., and Pilkey, O. H. (Eds.), Geology of Continental Slopes. Soc. Econ. Paleontol. Mineral. Spec. Publ., 27:75-82.

Middleton, G. V., and Hampton,, M. A., 1973. Sediment gravity flows: mechanics of flow and deposition. Turbidites and Deep Water Sedimentation. Soc. Econ. Paleontol. Mineral., Pacific Sec. Lecture Notes for Short Course.

Milliman, J. D., 1974. Marine Carbonates: New York (Springer-Verlag).

Mutti, E., and Ricci Lucci, F., 1975. Turbidite facies and facies associations. Examples of Turbidite Facies and Facies Associations from Selected Formations of the Northern Appennines. Ninth Internatl. Congr. Sedimentol., Nice, France, Field Trip Guidebook A 11: 21-36.

Nardin, T. R., Hein, F. J., Gorsline, D. S., and Edwards, B. D., 1979. A review of mass movement processes, sediment acoustic characteristics, and contrasts in slope and base-of-slope systems versus canyon-fan-basin flow systems. In Doyle, L. J., and Pilkey, O. H. (Eds.), Geology of Continental Slopes. Soc. Econ. Paleontol. Mineral. Spec. Publ., 27:61-73.

Walker, S. T., 1984. Sedimentary structures of the west Florida slope and eastern Mississippi cone: distribution and geological implications [M.S. thesis]. University of South Florida, St. Petersburg.

Ward, W. C., 1976. Carbonate sand and gravel on the shallow shelf, northeastern Yucatan peninsula. In Weidie, A. E., and Ward, W. C. (Eds.), Carbonate Rocks and Hydrogeology of the Yucatan Peninsula, Mexico: New Orleans (New Orleans Geol. Soc.), pp. 35-44.

Date of Initial Receipt: 5 February 1985

Date of Acceptance: 10 October 1985 